\title{
Supporting Native American girls during the COVID-19 pandemic
}

\author{
Lisa Polen \\ Population Council \\ Kelly Hallman \\ Population Council \\ Stephanie Martinez \\ Kassel Franco Garibay
}

Follow this and additional works at: https://knowledgecommons.popcouncil.org/departments_sbsr-pgy How does access to this work benefit you? Let us know!

\section{Recommended Citation}

Polen, Lisa, Kelly Hallman, Stephanie Martinez, and Kassel Franco Garibay. 2021. "Supporting Native American girls during the COVID-19 pandemic," IMAGEN brief no. 7. New York: Indigenous Adolescent Girls' Empowerment Network (IMAGEN). 


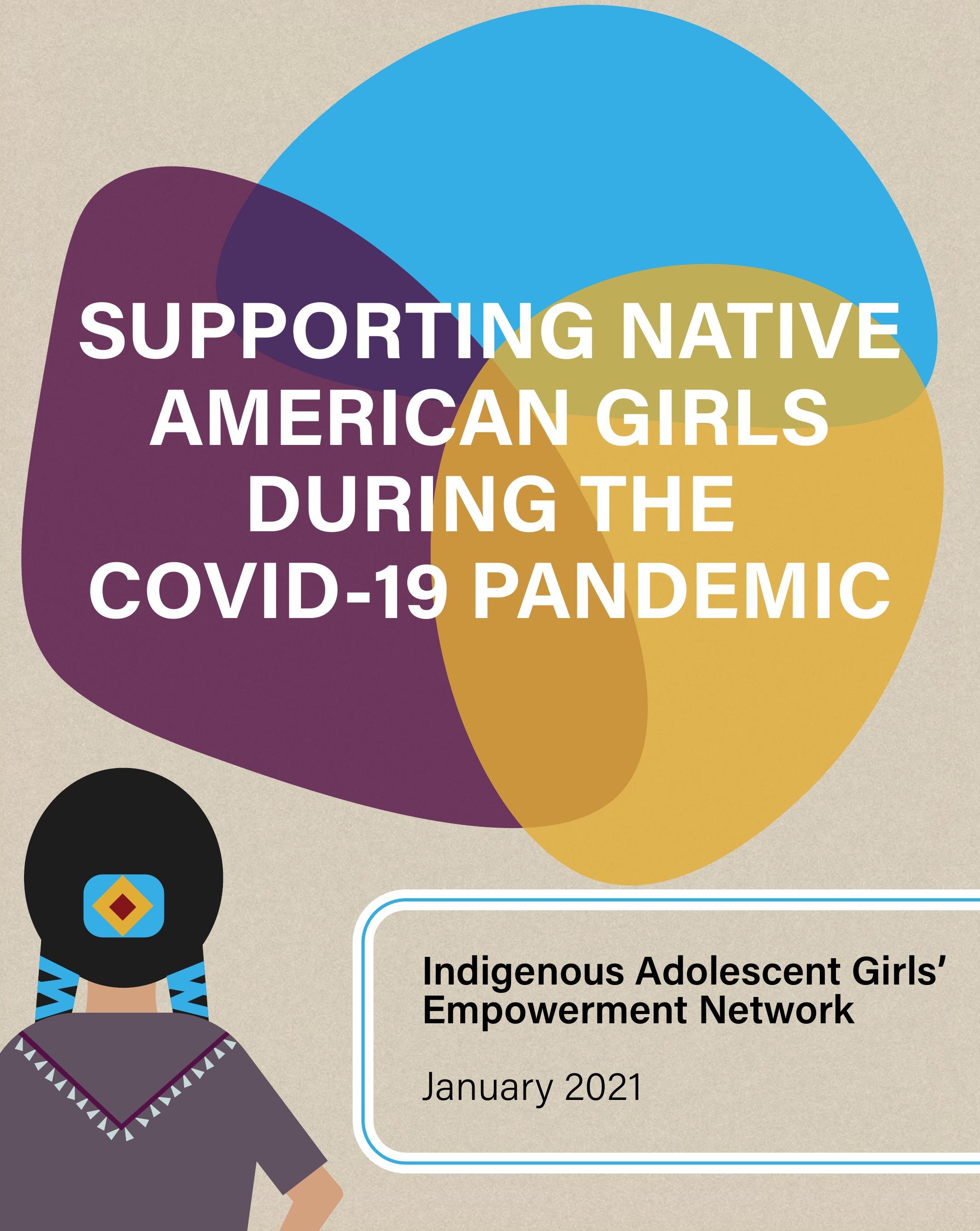




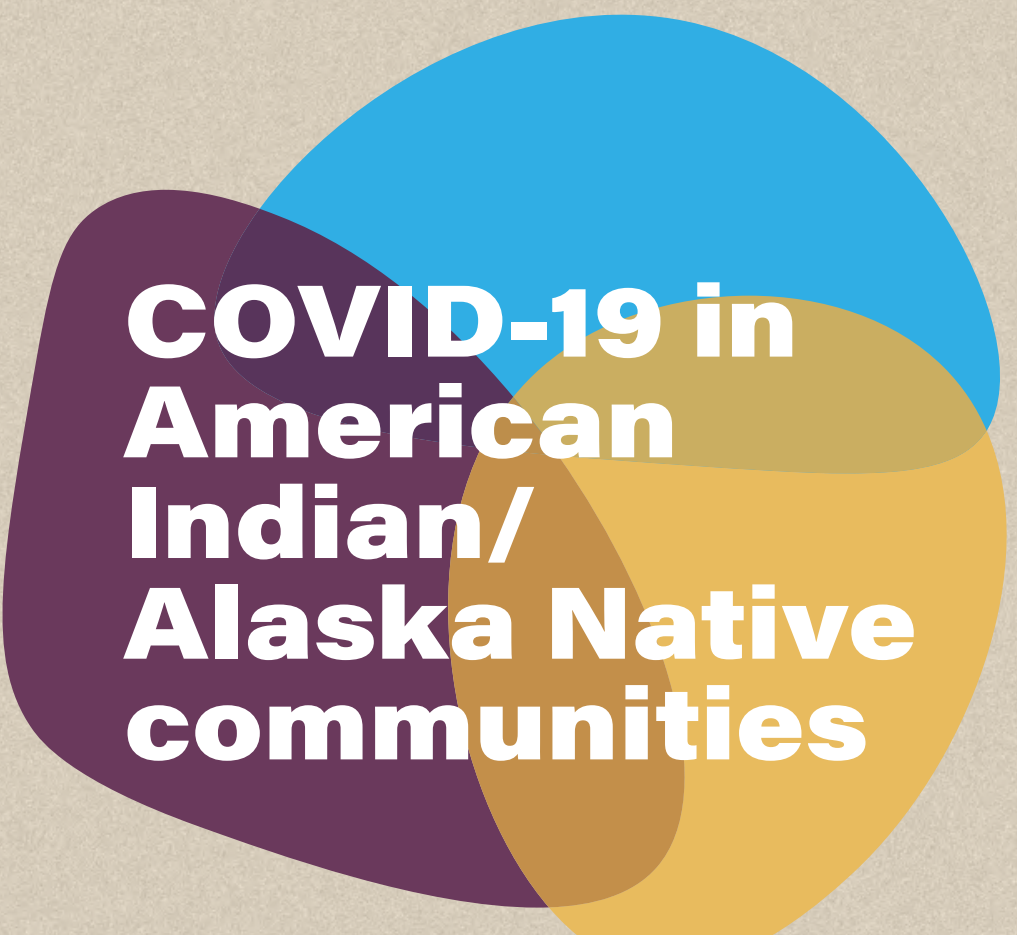

Coronavirus has had a devastating impact throughout "Indian Country" (geographic areas of sovereign, legally-recognized Native Nations) in the U.S. - the CDC reports the cumulative incidence of COVID-19 cases among American Indians (AI) and Alaska Natives (AN) is $3.5^{i}$ times that of nonHispanic whites." COVID-19 has a deadlier impact on the Al/AN population as well, with the likelihood of hospitalization 4.0 to 5.3 times, and mortality 1.8 to 2.6 times, that of non-Hispanic whites. iii Moreover, among persons aged 20-29 years, 30-39 years, and 40-49 years, COVID-19 mortality rates among $\mathrm{Al} / \mathrm{AN}$ are 10.5, 11.6, and 8.2 times, respectively, those of non-Hispanic whites. ${ }^{\text {iv }}$

COVID-19 has magnified existing disparities. Decades of deep, historic neglect have resulted in an underfunded health system, crowded and insufficient housing, persistent food insecurity and a high burden of chronic disease in Indian Country. Many live in multi-generational homes with numerous family members, making social distancing impossible and increasing risk for elders in the community. As lockdowns were implemented in many rural tribal communities, it became apparent that girls and their families would face increased risks of various types. Food insecurity increased since many families live at or below the poverty level and have limited financial and geographic access to groceries and supplies during lockdown periods. Girls are cut off from their sources of socioemotional support - schools, community groups and friends.

Al/AN youth already having among the worst high school graduation and teen suicide and teen pregnancy rates in the U.S.. As schools were shut down and students sent home, Al/AN girls already a vulnerable subgroup within this neglected population - faced increased risks. Many AI/AN girls live in unstable situations and have limited access to broadband and cell phone service, which threatens school progress as well as reducing teleoptions for counseling, health services, mentor contact, peer bonding and social support. 


\section{Location of IMAGEN COVID-19 Relief Recipients}

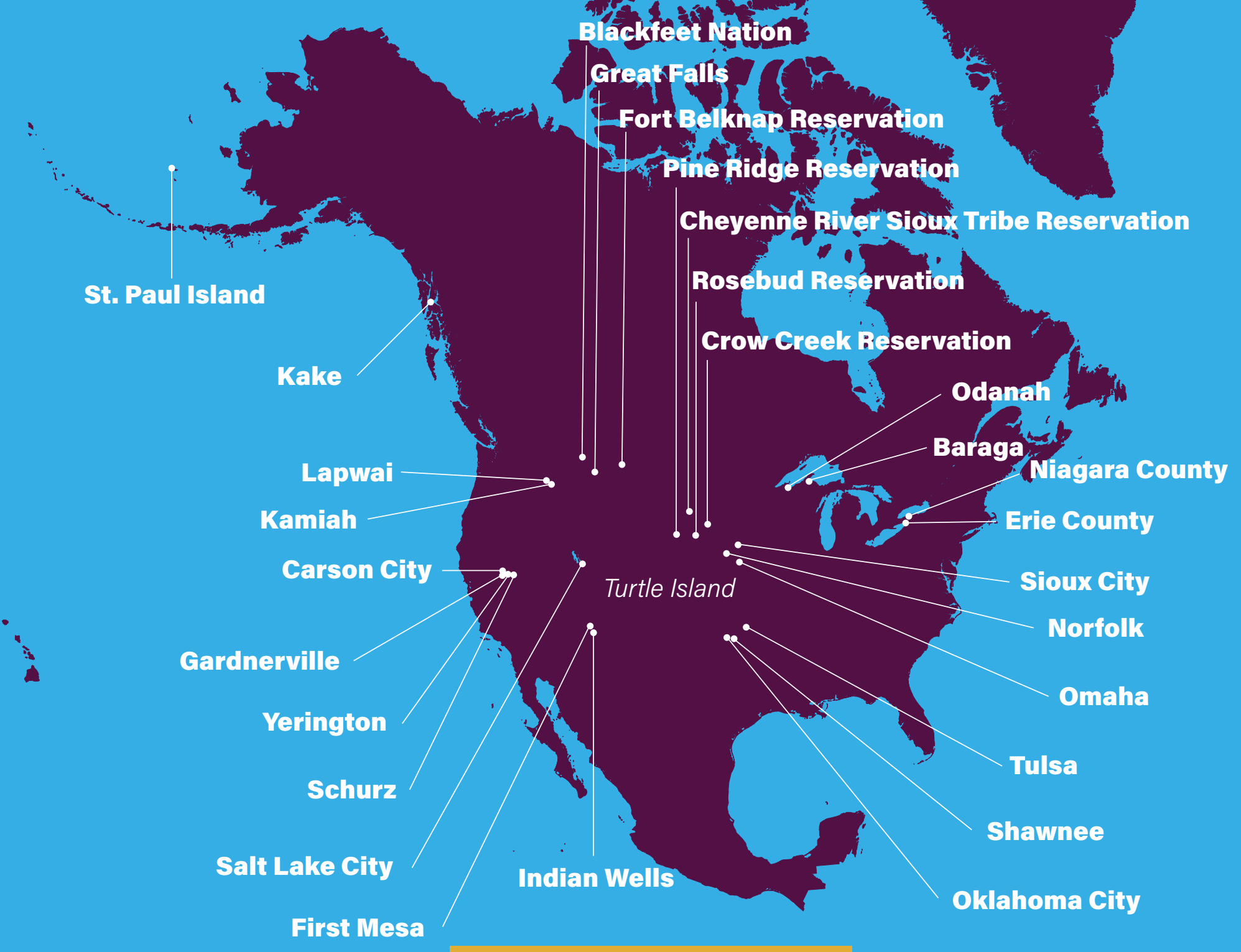

\section{Relief Recipients}

Alaska

St Paul Island

Kake

Arizona

First Mesa

Indian Wells

Idaho

Kamiah

Lapwai

lowa

Sioux City

Michigan

Baraga

Montana

Blackfeet Nation
Babb

Browning

Fort Belknap Reservation

Great Falls

Nebraska

Omaha

Norfolk

New York

Niagara County

Erie County

Nevada

Carson City

Gardnerville

Schurz

Yerington
Oklahoma

Oklahoma City

Shawnee

Tulsa

South Dakota

Cheyenne River Sioux Tribe

Reservation

Eagle Butte

Dupree

Timber Lake

White Horse

Crow Creek Reservation

Pine Ridge Reservation

Kyle

Martin
Pine Ridge

Porcupine

Rosebud Reservation

Antelope

Mission

Okreek

Parmalee

Rosebud

Spring Creek

Saint Francis

White River

Utah

Salt Lake City

Wisconsin

Odanah 


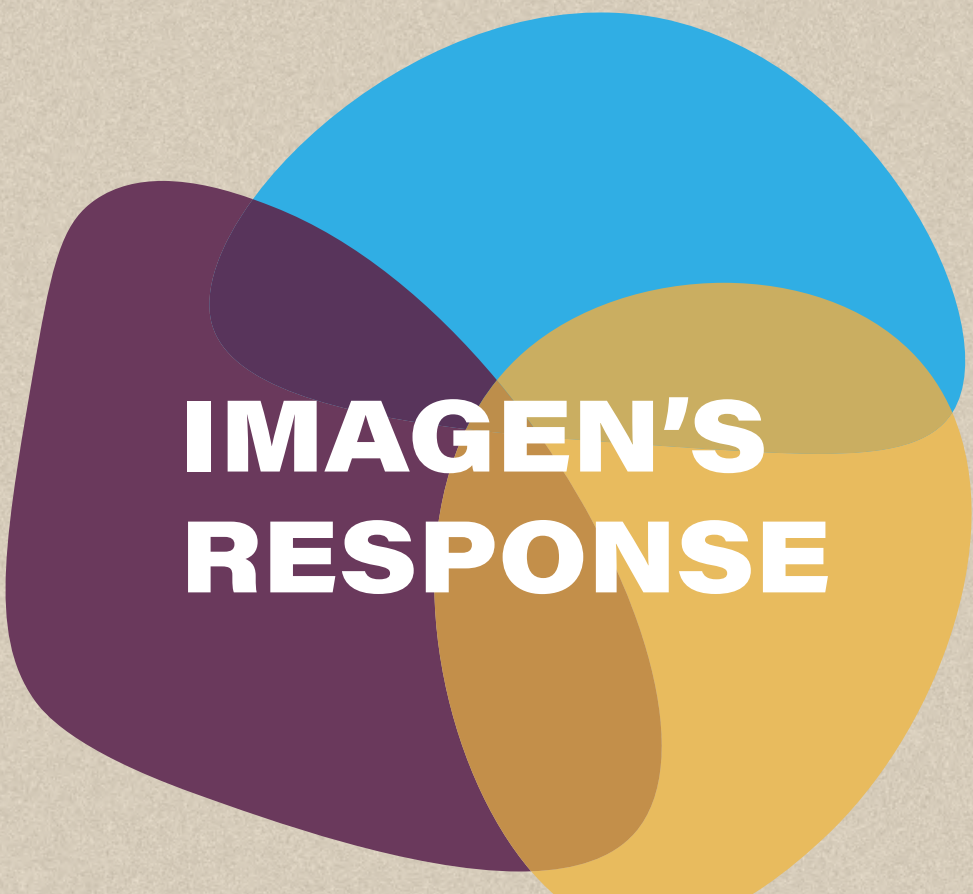

The Indigenous Adolescent Girls' Empowerment Network (IMAGEN) is a native female designed, led, and controlled network that adapts, builds, and shares innovative skills and tools to create local Girl Societies that address the needs of AI/AN adolescent girls. Building from decades of programmatic research and lessons learned with indigenous girls across the Americas, IMAGEN brings AI/AN females and organizations together to build state-of-theart approaches to reclaim matrilineal traditions and accompanying female social infrastructure. Through the Girl Society framework, girl-centered programs are adapted to the local context and impart tribally determined skills, safe havens, and mentor networks to girls.

Through the generosity of a private donor, Mr. Marty Jeiven, IMAGEN received $\$ 36,000$ to directly fund groups that work with AI/AN adolescent girls. To reach as many girls as possible, IMAGEN created micro-grants ranging from $\$ 500-\$ 2,000$ that were dispersed to Native women working with local girls. We received applications from teachers, domestic violence advocates, health professionals, community organizers and child welfare specialists. Between May and October 2020 IMAGEN administered 68 micro grants to 33 Girl Society groups working in 44 communities, reaching over 600 girls. IMAGEN's reach has been broad; we funded groups working with girls in cities, towns and rural tribal communities in 14 states, including Alaska, Arizona, California, Idaho, lowa, Michigan, Montana, Nebraska, New York, Nevada, Oklahoma, South Dakota, Utah, and Wisconsin.

Groups were innovative in using funds to maintain strong connections with the girls in their communities during a time of isolation and limited access to support systems (see Box 1). Many groups created supply kits that were delivered to girls at their homes and that responded to the unique needs in their communities such as self-care items, gardening, art and mask-making supplies as well as emergency supplies - including food, cleaning supplies, handsanitizer, diapers and baby supplies, water and masks for those under lockdown. 


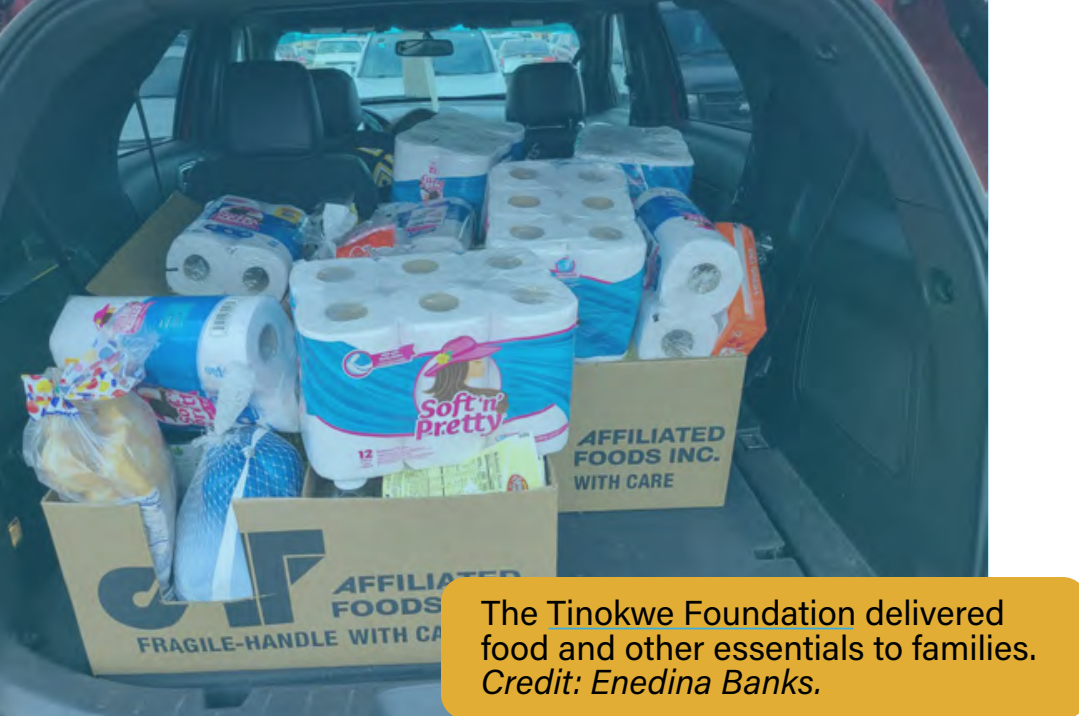

During the pandemic, IMAGEN has continued to connect and support the women running Girl Society groups. All microgrant recipients became members of the IMAGEN Circle and are invited to the IMAGEN bi-weekly support and check-in meetings where network members share ideas

The Thunder Valley WWHY Girls Society provided craft and hygiene supplies after learning that girls needed community-focused activities following COVID-19 shutdowns. and resources for connecting with girls during COVID-19 and plan for the future beyond the pandemic. IMAGEN facilitates these calls, announces available funding and workshop opportunities, and provides technical assistance to all members of the network. IMAGEN Circle members have the chance to present their work during regularly scheduled IMAGEN webinars that reach a large audience of practitioners, donors, researchers and Girl Society leaders. 


\section{Box 1. List of Activities} funded by IMAGEN's COVID-19 Emergency Fund

\section{FOOD INSECURITY}

Food parcels assembled by and for girls in foodinsecure families

Provision of supplies for virtual baking and cooking sessions which are extremely popular

Baby food distributed to teen mothers

Gardening supplies, seeds and food preservation equipment provided to girl-managed gardens

\section{FINANCIAL NEEDS}

Emergency cash distributed

Financial assistance to girls in the greatest need, including homeless girls

Collection and distribution of winter gear and PPE

\section{HYGIENE}

Hand sanitizer, soap, lice treatment, and oral hygiene products provided in wellness packages

Diapers and baby wipes delivered to teenaged mothers

Feminine hygiene supplies, puberty kids and underwear for girls in deep remote areas

Virtual puberty education classes offered

\section{ENSURING SPIRITUAL WELL BEING}

Prayer materials such as sage, cedar, sweetgrass and prayer bundles were widely distributed

Virtual prayer and healing circles for girls held weekly

\section{CULTURAL AND COMMUNITY SUPPORT}

Sewing kits for girls to produce PPE for elders, themselves and other relatives

Materials for producing cultural objects (moccasins, beading, ceremonial dresses, parfleche bags, and medicine pouches), and art supplies (paint, drawing paper, and pencils) provided to girls

Connecting girls still at boarding school to girls in home communities through virtual groups, pen pal activities, journaling, gaming and greeting card making

Virtual photography bootcamp including purchasing equipment so girls can learn to create content and develop editing skills

\section{WELLNESS, PHYSICAL AND MENTAL HEALTH}

Self-defense classes offered to girls via live instruction from local experts

Self-care and wellness kits including journals, beauty and wellness supplies

Exercise supplies including jump ropes, hula hoops, and resistance bands included in wellness kids

Purchasing gear for outdoor education, small group hiking trips, backpacking and rock climbing

Support for physical activity including girls' basketball and a 10-mile bike, walk and run challenge club for girls

Substance abuse prevention, creating social media campaigns, PSAs and community outreach

\section{COMMUNICATION AND CONNECTION}

Provision of cell phones and fee coverage for broadband where available and communication apps

Live, virtual group gatherings to provide girls with social support, fun, and organized activities

Incentives such as gift cards for girls to join virtual meetings, ceremonies and other community events to keep them engaged and connected with each other 


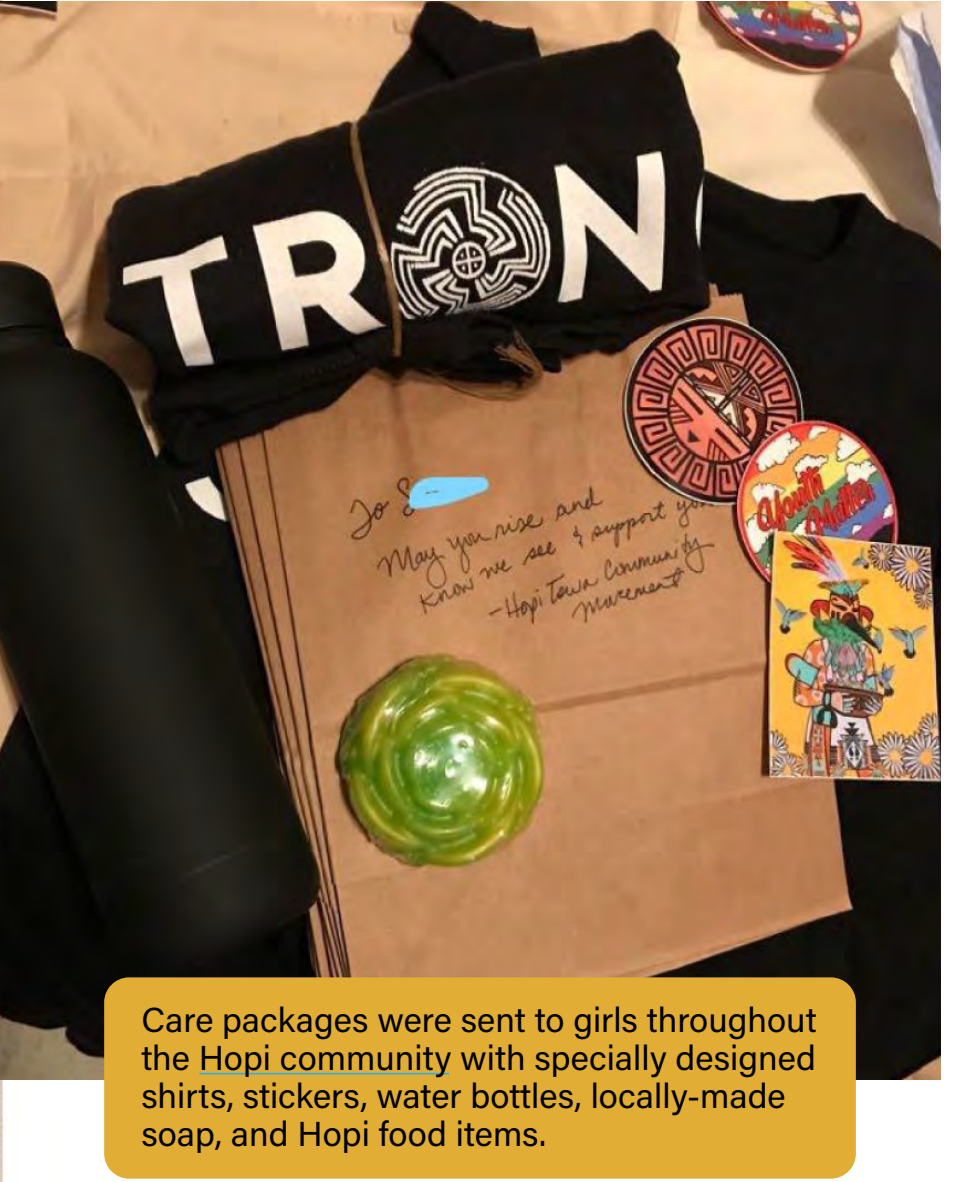

Care packages were sent to girls throughout the Hopi community with specially designed soap, and Hopi food items.
Citation: Lisa Polen, Kelly Hallman, Stephanie Martinez, Kassel Franco Garibay. 2021.

Supporting Native American girls during the COVID-19 pandemic. Indigenous Adolescent Girls' Empowerment Network (IMAGEN) Brief.

7. New York, NY. https://doi.org/10.13140/ $\underline{R G .2 .2 .15118 .48963 / 2}$
These figures include data from 23 states that report race/ethnicity information. Arizona which has had a large outbreak is not included in these data.

i Hatcher SM, Agnew-Brune C, Anderson M, et al. COVID-19 Among American Indian and Alaska Native Persons - 23 States, January 31-July 3, 2020. MMWR Morb Mortal Wkly Rep 2020;69:1166-1169, DOl: http://dx.doi. org/10.15585/mmwr.mm6934e1

CDC COVID-19 Hospitalization and

Death by Race/Ethnicity: https://www.cdc. gov/coronavirus/2019-ncov/covid-data/ investigations-discovery/hospitalization-deathby-race-ethnicity.htm|

Arrazola J, Masiello MM, Joshi S, et al. COVID-19 Mortality Among American Indian and Alaska Native Persons - 14 States, January-June 2020 MMWR Morb Mortal Wkly Rep 2020;69:18531856. DOl: http://dx.doi.org/10,15585/mmwr.
The Fort Belknap Girls Society sent packages with items to create important cultural pieces such as old style shawls and trade cloth purses. The girls attended Zoom sessions to learn how to use the supplies to create these traditional items.

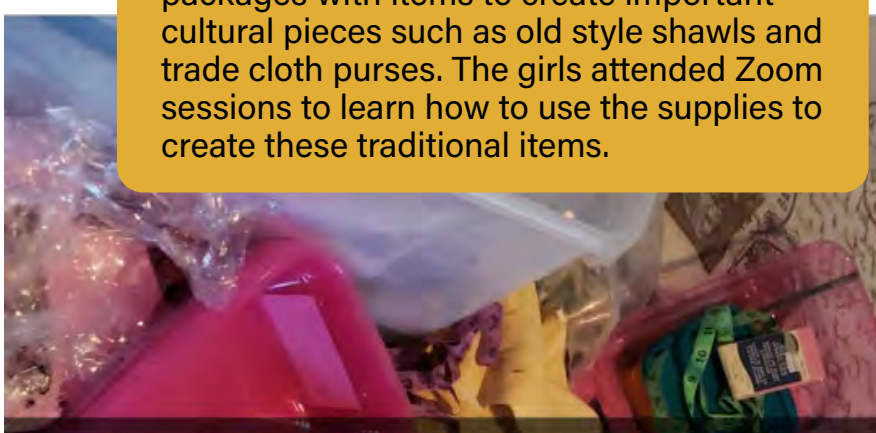

Girls society kits today, delivering tomorrow

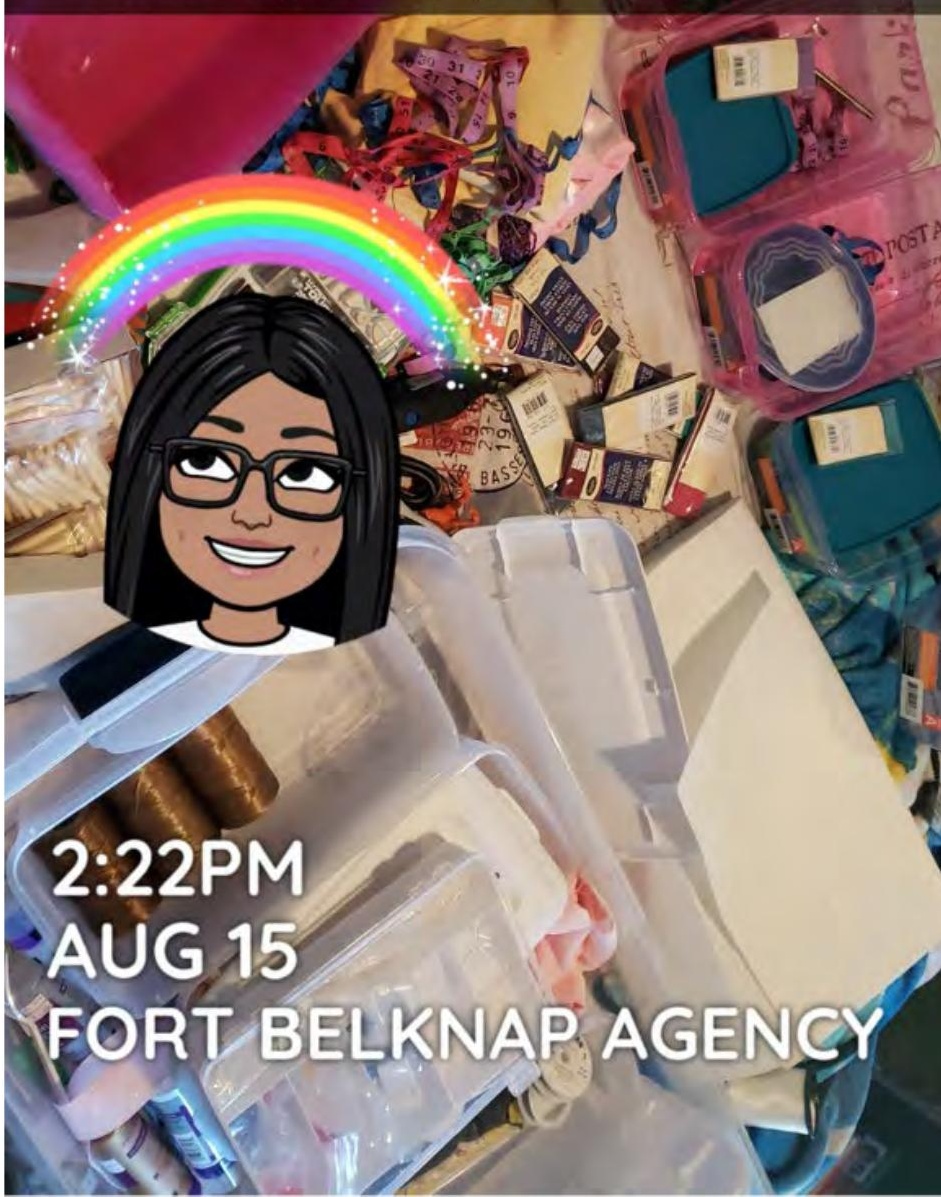


